\title{
A „Harari-jelenség” - töprengések a tudományos sikerről és a teljesítményről
}

\author{
KRÉMER BALÁZS ${ }^{1}$
}

\section{Bevezetésféle}

Talán tőlem hallottak először debreceni egyetemi kollégáim - köztük a Metszetek szerkesztői is - Youval Noah Harariról, az izraeli történészről, illetve magyarul is megjelent könyveiről (Sapiens, Homo Deus, 21 lecke a XI. századról). Rám mély benyomást tett különösen első, és szerintem legjelentősebb könyve a Sapiens. Letagadhatatlanul tetszett szarkasztikus és önreflexív, könnyed és elegáns, provokatív, sőt szemtelen mesélő stílusa, élvezetes olvasmányossága - no meg, elgondolkodtató okfejtése.

Ezzel együtt, Harari sztorija nem egy szokványos tudományos sikersztori, hanem sokakat zavarba ejtő egyensúlyozás a tudományosság határvonalán, amely sajátos mondandó és stílus korábban elképzelhetetlen, legfeljebb krimi és romantikus bestseller-szerzőkével összemérhető sikert hozott a példányszámokban szerzőjének. ${ }^{2}$

Azután kollégáim is elolvasták Harari könyveit, és ez jól érzékelhetően elgondolkodtatta, sőt zavarba is hozta őket. Amikor gyanútlanul, egészen más ügyben keresve őt, bementem tanszékvezetőm irodájába, és ott a Metszetek szerkesztői tartottak szerkesztőségi ülést - egyszer csak valaki megszólalt, hogy nem lenne-e kedvem röviden összefoglalni és megírni gondolataimat erről a „Harari-jelenségről”? Mivel e jelenség engem is foglalkoztatott, könnyelműen rávágtam, hogy „miért is ne? Természetesen igen”. Meg is állapodtunk egy határidőben, ami már réges-régen elmúlt - pedig gyakran gondoltam adósságomra. Azután meg, sok-sok töprengés után - hát mégis megírtam...

\section{A siker meg a teljesítmény}

Abban, hogy össze tudtam rendezni gondolataimat, nagy segítségemre volt a Hararit jó messzire leszakadva, de mégiscsak ezernyi hasonlóságban követő szerző, Barabási

\footnotetext{
${ }^{1}$ Debreceni Egyetem, Szociológia és Szociálpolitika Tanszék. E-mail: kremer.balazs@arts.unideb.hu

${ }^{2}$ Nem fogok egyenként hivatkozni munkáira, akit érdekel, az valamennyi nyelven megjelent valamennyi könyvét, cikkét, a vele készült interjúkat és nyilvános beszédeit megtalálja saját honlapján: ynHarari.com.
} 


\section{VÉLEMÉNY}

Albert-László könyve, „A képlet”. ${ }^{3}$ Barabásit a hírnévben, ismertségben, elismerésben, díjakban és igencsak nyomatékkal a pénzben mérhető „külsődleges” siker okai és magyarázatai érdeklik (és naná, egy hálózatkutató mi másban is találhatná meg ezen magyarázatokat, mint a hálózatokban...), de ehhez szüksége van egy nagyon fontos elhatárolásra. Szét kell választania a leginkább belülről, elégedettségként megélt, többnyire nem is mérhet” „teljesítményt”, és a külsődleges, nagyon is mérhető „sikert”. E siker jellemzésében némiképp a piaci marketingszemléletet adaptálja a sport, a múvészet vagy éppen a tudomány világára is. A siker szempontjából nem az a lényeges, hogy ki vagy, mi vagy, mi a teljesítményed - hanem az, hogy a bármilyen, gyakorta nem is túl jelentős teljesítményedet miképpen tudod „eladni”, terjeszteni, hogy „mennyire látszol” sikeresnek, milyen kívülről érkező jutalmakra tudsz szert tenni, és hogy ezek alapján „mennyire tartanak” sikeresnek.

Ez a megosztás már elég jó „keretnek”, keretezésnek tűnik ahhoz, hogy rendezni tudjam gondolataimat a Harari-jelenségről, hogy értelmezni tudjam a Harari-sztorit.

\section{A siker...}

Harari sztorija leginkább „sikersztori”. Méghozzá akkora nagy sikersztori, hogy hasonlót a társadalomtudományi (vagy legalábbis társadalomtudományos ismeretterjesztési) világ még nem nagyon tapasztalt. Nem csupán könyveinek eladott példányszámában, abban, hogy hány nyelvre fordították le munkáit, hanem mindabban, ahogyan elfoglalta - nem csupán a tudományos, hanem a legszélesebb - nyilvánosság tereit. Szintén a világ minden táján, közte a legnagyobb, legolvasottabb világlapoknak és TV-knek ezernyi interjút adott; nagy sikerű, akár ezres közönség előtt író-olvasó találkozókon promotálta munkáit; és meghívást kapott előadást tartani a világ különböző politikai és gazdasági csúcstalálkozóinak plenáris üléseire (legutóbb a World Economic Forumra), amely előadásait szintén élőben közvetítették a világ vezető hírcsatornái. Barabási azon tanulságát, amely szerint egy idő után maga a siker is újabb sikereket szül, Harari példáján is lehet demonstrálni: minél sikeresebb lett, annál többen, köztük politikusok vagy népszerű celebek is elismeréssel, fontos olvasmányként emlékeztek meg Harariról - amitől persze még többen olvasták, messze nem csak a társadalomtudományhoz közelállók, hanem mindenki. No persze, konkrét példányszámokról, vagy az abból kikövetkeztethető pénzügyi nyereségeiről nincsenek konkrét információk - de anyagi helyzete miatt sincsen aggodalomra oka senkinek sem.

Harari sikerei mögött azt hiszem, hogy nincs túl nagy titok - a gazdasági élet más területein bevált gyakorlatokat úttörő módon ültette át a társadalomtudomány világára.

\footnotetext{
${ }^{3}$ Barabási A. L. (2018): A képlet - A siker egyetemes törvényei. Budapest, Libri Kiadó.
} 


\section{VÉLEMÉNY}

Már maga a termék, az írás is éppúgy sikerorientált, ahogyan azt a marketing tankönyvek tanítják: nem a meglevő, kész terméket kell reklámozni és eladni - hanem már eleve a vásárlói igényeknek megfelelően kell létrehozni a terméket. Harari minden leírt szava e marketing-megfontolásból is alaposan lektorált, amint munkáinak egész szerkezete is. Akár a precíz és szabatos kifejtés tudományos korrektségéből is áldozva, rövid és világos mondatokban, egyszerűen fogalmazva meséli el a maga történetét. Mindez nem teljesen új, előzmények nélküli jelenség a társadalomtudományban. Míg a XX. század második felét a németes filozófiai hagyományt követő, barokkosan tekervényes mondatokban fogalmazott nyelv jellemezte (olyannyira, hogy sokan a nem ilyen, nem olvashatatlan nyelven megírt munkákat nem is tekintették „igazi” tudományos munkának), addig az új évezred társadalomtudományi nyelvében egyre meghatározóbb az amerikaias, különösen a „nagy közgazdászok” által használt mesélős, gyakran önéletrajzi anekdotákba ágyazott tudományos stílus. (Több Nobel-díjast is e stílus művelői közé lehet sorolni: a magyarul is olvashatók közül Sen, Kahneman, Thaler, Deacon, Akerlof, Shiler stb.) Ám Harari könnyed stílusa még rajtuk is túltesz, akár végletes leegyszerűsítések és rövidítések árán is. (Gondoljunk csak bele, micsoda egetverő szemtelenség az emberiség 70 ezer éves történetét háromszáz oldalba sűrítve elmesélni - ahogyan azt a Sapiensben megtette...) Ez a leegyszerűsített és tömörített nyelv ugyanakkor elképesztően fegyelmezett is, ami tovább javítja könnyű követhetőséget és olvashatóságot: semmi leágazás, semmi kacskaringó, semmilyen tiszteletkör se jobbra, se balra - a mondandóját világos, egyszerű, lineáris szálra fűzi fel, amely szálon könnyű lépésről lépésre haladni.

Másfelől, Harari mögött egy épp olyan marketing és ügynöki szervezet áll, mint amilyen a piaci termékeket „teríti”. Jól szervezett kereskedők, reklámosok, lobbisták, és velük együtt dolgozó kampányszervezők, dizájnerek, kommunikációs szakemberek. Harari ebben a sikerorientált üzemmenetben nem is igazán a dolgok menetének irányítója, nem a „főrendező”, hanem inkább a szerepét eljátszó primadonna és bonviván főszereplő. Nyilvánvalóan 2-3 évre előre, napra és percre be van osztva az, hogy a Föld mely részén van fellépése, mikor kinek ad interjút, hol szólal fel, és hol jelenik meg könyve újabb kiadásának bemutatóján. (Nem irigylem érte - de a siker ezzel jár.)

Ilyen „üzemet” a társadalomtudományi műhelyek soha nem tudtak megszervezni legfeljebb erőforrások nélkül is, utánozgatni próbálták ezt az üzemmenetet. Ami nemcsak az amatőrség miatt hozza zavarba a társadalomtudományok művelőit, hanem...

Hanem - mint azt Barabási is regisztrálja - azért, mert valójában a társadalomtudományok is az elmúlt években nem a társadalom felfedezésében, értelmezésében és magyarázatában való teljesítményre, hanem a külsődleges megítélés, elismertség, popularitás elveit követő sikerre rendezkedtek be. Mindaz, amit a társadalomtudomány elvár és értékel a művelőitől, az a siker, és a sikeresség mutatói: minél több (akármilyen) publikáció megjelentetése, minél magasabb presztízsű helyeken, minél több hivatkozás és hatás - no meg, minél több projekt, ami csupán szemérmesen 


\section{VÉLEMÉNY}

belterjes megfogalmazása annak, hogy: minél több pénz. A tudománymetria mutatói között semmilyen indikátora nincsen a tudományos eredmények minőségének, a tudományos kutatásban nyújtott teljesítménynek, ehelyett minden mutató a külsődleges befogadást és elismerést kifejező „siker-indikátor”. A tudományos munka ezen túl is ehhez igazította a napi múködésmódját: bármilyen is a produktum, a termék, a jobb teljesítménynél fontosabb elvárás a hálózati network, némi túlzással, a smúzolás. Akár dögunalmas konferenciákon és workshopokon való hetyegés, projekt és kutatói konzorciumokba való beférkőzés, neves (értsd: sikeres) társszerzőkkel való közös publikálás stb.

Nos, hát Harari sikere emiatt majdnem sokkolóan zavarba ejtő a társadalomtudományok képviselői számára. Mert bár a szokásszerúvé és intézményesültté vált masinériáiban maguk a társadalomtudósok is a sikert hajhásszák - ám e szokássá, rendszerré intézményesült sikerorientált múködésmódban megközelíteni sem bírják Harari egészen más úton, egészen más eszközökkel elért kirobbanó sikereit.

\section{A teljesítmény...}

Barabási szintén felemlegeti azt a banalitást, amely szerint olykor jelentős teljesítmények semmiféle sikert nem hoznak azoknak, akik a jelentős teljesítményt létrehozták - de minden sikerhez azért kell valamiféle érzékelhető teljesítmény is. Bár a siker „mennyisége” egyáltalában nem korrelál a teljesítmény mértékével, azért valamilyen teljesítménynek mégis kell állnia mögötte.

A Harari-jelenség amiatt is zavarba ejtő, hogy sokak szerint egyáltalán nincsen mögötte jelentős tudományos teljesítmény, és ha mégis volna, akkor az a sikerek gyarapodása mellett is egyre romló. (Sokak szerint már a három könyve is minőségében egyre gyengébb, régóta nem jelent meg újabb könyve, és újabb interjúiban egyre többször ismétli magát. Mondhatjuk: a sikerre berendezkedett üzemmenet, a napi gyakoriságú megjelenés és megnyilatkozás annyira „kizsigereli”, hogy sem ideje, sem türelme, sem energiája nincsen mindig újabb ötletekkel elő́llnia, újabb teljesítményt prezentálnia.)

Harari teljesítménye a tudományos mércék szerint, már csak formai okokból sem tekinthető túl jelentősnek. Bár olvasottsága és műveltsége letagadhatatlan, de állításait hivatkozásokkal nem, vagy csak a kötetei végén szereplő irodalomjegyzékben ritkán és gyengén támasztja alá, nem érvel, nem ismerteti és kritizálja a mondandójával konkurens korábbi és újabb állításokat, és így nem is nagyon érvel mondandója mellett, nem igazol és nem bizonyít. Szellemesen és frappánsan elmondja a magáét, megnyerő és meggyőző modorban kinyilvánítja a maga igazságát. Amely magatartás szemben áll azzal a hagyományos tudományos attitűddel, amelyben az ötlet, a sejtés, a hipotézis, az a tudomány „művészies inspirációja” - az igazi tudományos munka és teljesítmény, az a „ráérzett” állítások kifejtése, alátámasztása és bizonyítása. Nem, Harari ilyenekkel nem sokat bajmolódik, és ha ez, az akkurátus tudományos bizonyí- 


\section{VÉLEMÉNY}

tás a tudományos teljesítmény „igazi lényege”, akkor a teljesítménye valóban nem túl jelentős.

Én ezt egy kicsit másképp ítélem meg, akkor is, ha Harari inkább a sikerre „hajt”, és ha a teljesítménye eközben a szokásos megítélés szerint valóban nem túl jelentős. De, ettől még van. Ennek megértéséhez ismét nem árt felidézni a manapság gyakorolt társadalomtudománnyal szemben egyre élesebben felvetett kritikákat.

A társadalomtudományokat gyakran kritizálják azzal, hogy különösen a közgazdaságtan, a szociológia és a pszichológia területén már elfogadottan elégséges pusztán matematikai-statisztikai apparátusokat bűvölgetni, minden különösebb hipotézis és elméleti háttér nélkül is. Hogy az eredetileg az érték, a közjó mibenlétét taglaló filozofikus közgazdaságtanból mára pusztán ökonometria lett, hogy más társadalomtudományok területén is elfogadott gyakorlat a pusztán adatokkal, számokkal való bűvészkedés. Amihez sokan hozzáteszik azt, hogy ez a fajta tudomány, ez nemcsak a világ értéséhez és értelmezéséhez járul hozzá kevéssel, de ismeretelméletileg is gyenge lábakon áll: ha a gépbe jó sok adatot betöltenek, akkor abból mindig ki is jön majd valami. Olykor jó adatokból jobb eredmények, de a szemét betöltéséből mindig csak szemét is fog kijönni.

Mások ennél gyengébben fogalmazzák meg a hasonló kritikáikat. Ők ugyanezt a tudományos gyakorlatot megfigyelve azt látják, hogy gyakorta a kutatók az adatok bűvölése után „barkácsolnak hozzá” elméleteket. Amely barkácsolt elméletek olybá tűnnek, mintha elméletekből a hipotézisalkotásra levont, valódi elméletek lennének, sőt, mivel azokat a már kész eredményekhez barkácsolták hozzá, emiatt még konzisztensnek is tűnhet a tudományos munka. Ám manapság ez az elméleti barkácsolás egyre gyakrabban bukik el a tudományosság legelemibb kritériumán: a barkácsolt elméletek alapján nem reprodukálható sem maga a kutatás, sem annak eredménye.

Végül a tudományosság amatőr sikerorientáltságának legdrámaibb lebukásai, azok a közönséges csalások lebukásai. Hogy számos empirikus kutatás egyszerűen hoax, svindli, csalás, vagy - különösen az orvoslásban, az epidemiológiában, a pszichológiában - egyre gyakrabban „meghekkelik” a mért adatokat, pl. a szignifikancia eredményekhez csak bizonyos méréseket vesznek figyelembe, másokat meg „eltemetnek". (Különösen gyakoriak ezek a lebukások az eleve érdekvezérelt tudományos megrendelések esetén, pl. a gyógyszergyárak új termékeinek klinikai tesztje során.)

Nos, minél inkább eltorzítja a sikerorientáltság a tudományos gyakorlatok korrekt, a hipotézisek tesztelésére, verifikálására-falszifikálására berendezkedett klaszszikus módszertanát - annál inkább felértékelődő teljesítmények a valódi, erős elméletek, elméleti hipotézisek. Amely elméleti feltevések, hipotézisek felvetéséhez nem szükségesek új felfedezések sem, gyakorta elég ismert jelenségeknek a szokásostól való eltérő értelmezése is.

Ha innen nézzük - akkor a Harari-jelenség megértéséhez figyelembe kell vennünk azt, hogy ő mer ismert jelenségeket másképp értelmezni, az ismert jelenségeket más értelmezési keretben, koncepcióban elhelyezni. Számomra ilyen a „vallás- 


\section{VÉLEMÉNY}

nak" az az értelmezése, amely eltér az istenhit szinonimájaként használt köznyelvi fogalomtól, és amely fogalom koncepcionális vezérfonal a Sapiensben.

Miközben - a tudományos normákhoz képest egyszerűen szemtelen. Úgy tesz, mintha nem lennének társadalomtudományi előzményei mindannak, amit és ahogyan ő elmond az általa elismert vallásról. Mintha nem hasonlítana nagyon az ő fogalomértelmezése Durkheimnek a társadalmi normákat társadalmi tényként való értelmezéséhez; mintha Machiavelli a jó törvényekről és a beléjük vetett hitről nem hasonlóan beszélne. Mintha a cselekvések koordinációjába nem tartozna bele a hatalom mint koordinációs elv, és nem lenne az istenhit-vallásnak akkora jelentősége a hatalom általi cselekvés-koordinációban, ahogyan azt Rousseau vagy Marx („a vallás a nép ópiuma") annak tulajdonítja. Az ortodox tudományetika szemszögéből udvariatlan, sőt szemtelen - aközben a saját logikájában következetes és erősen hat. Ha mindezen szerzőkre bármilyen kitételt tenne - akkor az egy-egy felesleges, a logikailag egyenes iránytól nélkülözhetetlenül eltérítő „kurfli” lenne - és akkor Hararinak már inkább a szemtelenség. Amely „előadásmódtól” eltekintve, ebben van teljesítmény, ha nincs is hozzá hivatkozás, tiszteletkör, elméleti felvezetés és a fogalom használatának igazolása, bizonyítása sem.

Valószínű, hogy ezt a „bizonyítás nélkül is értelmező” tudományos teljesítményt a társadalomtudományi-történelmi kérdésben járatos magyar olvasók könnyebben értik és értékelik, mint mások. A hazai történeti irodalom tudományos teljesítménynek értékel olyan szerzőket és műveket, akiket inkább publicistának vagy közírónak kellene tartanunk, és legfontosabb írásaikat ilyen munkáknak kellene elkönyvelnünk. Bár Hajnal István vagy Szűcs Jenő a középkori levéltári anyagok feldolgozásában minden pozitivista tudományos kritériumot is magasan teljesítettek, ám az o, valamint rajtuk kívül Bibó, Szabó Zoltán, Kemény István és mások által kifejtett „történelmi mélysodor teóriák” Harari okfejtéseihez hasonlóan nem igazán igazolt hipotéziseknek tekinthetőek. A fenti szerzők gondos alapossággal mutatják ki és igazolják azt, hogy a nyugatias és keleties feudális fejlődés jelentősen eltért egymástól. A nyugatias feudalizmus hűbéres rendszerének egyfajta, a jövőre irányuló szerződésféleség az alapja: a hűbérbirtok az uralkodó által megelőlegezett ellentételezése a jövőben megteendő hűbéres szolgálatoknak, pl. fegyveres és adóbehajtási szolgálatoknak. Ezzel szemben a keleties feudalizmus alapja az a vazallusi rendszer, amelyben a hűbérbirtok nem a jövőre irányuló szerződéses kötelességet alapoz meg, hanem az a múlt érdemeit honoráló kegy gyakorlása az uralkodó részéről. Ezen igazolt különbség ugyanakkor nem tekinthető bizonyíték erejű magyarázatnak arról, hogy a fejlődésben való, akár napjainkig ható kelet-európai társadalmi és gazdasági lemaradás oka ennek a kegygyakorló vazallusi hagyománynak a továbbélése - noha, sokunk számára erős sejtésünk az, hogy ebben akkor is „van valami”, ha az állítás nem tekinthető bizonyítottnak. (Tegyük most valóban zárójelbe, hogy a szociológia történeti módszertana, vagyis annak a paradigmája, hogy miképpen igazolható az, hogy korábbi történeti tények a ma társadalmi jelenségeit is meghatározzák - az 


\section{VÉLEMÉNY}

ismereteim szerint soha nem forrta ki magát, nem alakultak ki sztenderd szabályai.) Ám minden, a tudományos bizonyításra irányuló pozitivista norma alulteljesítése mellett is - a jeles szerzők által kifejtett, a történelmi mélysodrok, a kelet-közép-európai történeti fejlődés specialitásából levezetett történeti gondolat nemhogy a társadalomról való kultúránk része, hanem jelentős történeti-tudományos eredményként is nyilvántartjuk azokat. Ebben a „tudományosan korlátozott” értelemben azt hiszem, hogy Harari nem bizonyított, ámde fontos felvetései, értelmezései is eléggé jelentős társadalomtudományi teljesítményként könyvelhető el. (Újabb adalék ahhoz, hogy különösen a fentebb kritizált hibákba beleeső társadalomtudósok miért jönnek zavarba a Harari-jelenségtől.)

Végül, Harari tudományos teljesítményéhez még egy tényező hozzájárul. Mer a jövőről gondolkodni, és mer a jövőre vonatkozó következtetéseket is levonni gondolataiból - főképp a mesterséges intelligencia, a robotika, a környezeti problémák, a nacionalizmusok és a migráció várható alakulásáról. Hogy a jövőre vonatkozó predikció, előrejelzés, az „tudományos ténykedés” - ez már Descartes óta része a racionális hagyománynak. Descartes és követői, pl. Newton számára a múltban és a jelenben történt megfigyeléseknek az a legfontosabb értelme és célja, hogy abból „törvényszerüségeket”, természeti törvényeket állítsunk fel, amiből ha jól csináltuk, akkor hasonló körülmények között a jövőben megtörténő eseményeket is pontosan tudjuk előrejelezni. A kartéziánus racionalista hagyomány azt az attitűdöt, hogy a jelen és a múlt megfigyeléseinek a jövő kiszámíthatósága, a jövő kísértése a célja ezt mindmáig megtartotta, különösen a természettudományok világában. A társadalomtudomány mindig is kacérkodott és kacérkodik ezzel - de ritka kivételektől (pl. a közgazdászok előrejelzéseitől) eltekintve nem nagyon merte és meri ezt bevállalni. Amire van ok és mentség: a társadalmi jelenségek túl sok tényezőből tevődnek öszsze, túl komplex és túl sok változós összefüggéseket kellene felállítani ahhoz, hogy törvényszerűségeket lehessen felállítani és azokból előrejelzéseket lehessen tenni. De ettől még a racionális gondolkodás jövőt kísértő attitűdje, ha csak szemérmesen is, de tovább él.

Nos, Harari mer állításokat tenni a jövőről, és ezzel a szemérmeskedő tudományosságot szintén zavarba hozza. Jogosan. Jogos a zavarba esés is, meg a szemérmességet átlépő „teljesítmény” zavarba hozó sajátossága is. Aminek megítélésében vannak kétségeim. Egyfelől, én magam sem tudom megítélni Harari előrejelzéseinek helyességét és jogosságát - számos kérdésben (pl. a mesterséges intelligencia várható hatalmában) azt hiszem, hogy nem jogosak az előrejelzései (egyelőre semmi sem igazolja azt, hogy bármely mesterséges intelligencia bármit is „akarna”, akarhatna azok egyelőre kizárólag az emberi akaratok végrehajtásában nyújtanak elképzelhetetlenül erős és hatékony eszközöket - nem az algoritmusok hatalmától van okunk félni, hanem az azokat gátlástalanul használó emberekétől...).

De, bármennyire is vannak ellenvetéseim és ellenérzéseim Harari jövőre vonatkozó vízióiról, azt azért tudományos teljesítményként vagyok kénytelen elismerni, 


\section{VÉLEMÉNY}

hogy mer a jövőről beszélni. Hogy a popperi ismeretelmélet tudományos normái szerint mer vitatható állításokat megfogalmazni - amelyeket lehet vitatni, igazolni vagy cáfolni.

Bármennyire is nem a szokványos elvárások szerinti teljesítményként, és ettől zavarba ejtően - de vannak tudományos teljesítmény-értékei is Harari gondolatainak.

\section{Összegzésként}

A Harari-jelenség igazán zavarba ejtő...

Nekem leginkább azért, mert szemérmetlenül és gátlástalanul sikerorientált, amitől még inkább láthatóvá teszi azt, hogy a maga módján, a maga eszközeivel, a maga kereteiben nemcsak az alkalmazott tudományként gazdasági beszállító természettudomány hajt a pénzre, de a hagyományos társadalomtudomány is szemérmetlenül, gátlástalanul és önreflexiók nélkül sikerorientált. Másképp, máshogyan, de mégis. Ami attól ad töprengésre okot, hogy mi, társadalomtudósok, társadalomtudományokkal foglalkozók a társadalom megértésében nyújtott eredményekre mint teljesítményre orientáltként szeretünk magunkra tekinteni. Pedig, hát egy fenét. Mindaz, ami a társadalomtudomány elismerésében számít (a publikációk és hivatkozások száma, a projekt, és a projektekben megszerzett pénz stb.) - az külsődleges megítélés szerinti, a trendi témaválasztásban és annak eladásában, marketingben, smúzolásban és networkingben tett erőfeszítések nyomán előálló „siker”, és nem a világ értéséhez és értelmezéséhez hozzájáruló „teljesítmény”. Amit jobban és nagyobb szégyenkezéssel érzékelhetünk, ha végiggondoljuk a Harari-jelenséget. És amin lehet, hogy még van mód változtatni, a tudományt valóban a világ értésének és értelmezésében szolgálatot tevő ágenseként rehabilitálni.

Másrészt, Harari zavarba hoz azért, mert nem ad kész tudást, nem azért jó olvasni, mert abból valami tudományosan igazolt bizonyosságot tud meg az ember. Harari szemtelen és provokatív, akár üzleti és siker megfontolásokból is, de világosan, logikusan fejti ki mondandóját - ami arra ingerel, hogy lehessen vele világosan, logikusan vitatkozni.

Kell is. Amihez érdemes Hararit olvasni.

Harari számos cikkét, vele készült interjút, azok ismertetését magyarra is lefordították, és interneten ezek el is érhetőek.

\section{Három, magyarul is megjelent könyve:}

Sapiens - Az emberiség rövid története, Animus, 2015 (második kiadás: 2020) Homo Deus - A holnap rövid története, Animus, 2017 (második kiadás: 2020) 21 lecke a 21. századra, Animus, 2018 (második kiadás: 2019) 